University for Business and Technology in Kosovo

UBT Knowledge Center

Nov 7th, 9:00 AM - 5:00 PM

\title{
Analysis of Marmara Region Electrical Power System Stability under the Critical Fault Conditions
}

Nihat Pamuk

Turkish Electricity Transmission Company, nihatpamuk@gmail.com

Follow this and additional works at: https://knowledgecenter.ubt-uni.net/conference

Part of the Engineering Commons

\section{Recommended Citation}

Pamuk, Nihat, "Analysis of Marmara Region Electrical Power System Stability under the Critical Fault Conditions" (2015). UBT International Conference. 50.

https://knowledgecenter.ubt-uni.net/conference/2015/all-events/50

This Event is brought to you for free and open access by the Publication and Journals at UBT Knowledge Center. It has been accepted for inclusion in UBT International Conference by an authorized administrator of UBT Knowledge Center. For more information, please contact knowledge.center@ubt-uni.net. 


\title{
Analysis of Marmara Region Electrical Power System Stability under the Critical Fault Conditions
}

\author{
Nihat Pamuk \\ Turkish Electricity Transmission Company, 54100 Sakarya, Turkey \\ nihatpamuk@gmail.com
}

\begin{abstract}
Electrical power systems are such nonlinear systems that the ever changing working environments. Generator outputs, loads and the electrical power system parameters are continuously changing. In recent years, because of economic and environmental conditions, electrical power systems have been forced to work nearly maximum load capacity with the most efficient operating conditions. Accordingly, also, power flow and critical fault conditions analysis is a significant criterion for operation of electrical power systems. Modern power systems are planned for high level, multi-variable dy namic sy stems. In this study, 16 busbar section from 118 busbar interconnected 420 and $170 \mathrm{kV}$ Marmara region electrical power system transmission lines are discussed. Electrical power system stability is investigated under the critical fault conditions. Power flow and critical fault condition analysis of newly installed transmission lines, additional power transformers and power generating units possibly installed in coming future was performed. Power flow and fault analy sis of mentioned electrical power system are solved by using the Power Sy stem Analy sis Toolbox 2.1.9 (PSAT) software
\end{abstract}

Keywords: Critical Fault Condition, Electrical Power System Stability, PSAT

\section{Introduction}

Electrical energy is the most widely used type of energy and it is very valuable. But electrical energy is most expensive type of energy. Energy power system planners must make all kinds of researches and developments such as minimum cost, consumption and savings analyses. Electrical power systems are nonlinear systems that have ever-changing working environments. Loads, generator outputs and the system parameters are continuously changing.

In recent years, economic and environmental conditions have forced electrical power sy stems to work close to the border points of the most efficient operating conditions. Accordingly, analy sis of electrical power systems is an important criterion for operation. Modern electrical power systems are planned high level and multi variable dynamic systems. In general, the distortions in the electrical power system parameters are triggered by different characteristics of sy stem components [1]. Owing to ease of use, easily conversion of other types of energy and widespread use in daily life electric energy consumption has increased from year to year, and today the most important indicator for development level of countries is electrical energy consumption rates. The most appropriate way to meet these growing demands is possible with future planning schemes [2]. For this reason, application of power flow analy sis has become more important in electrical power systems.

System optimal operating points are determined by power flow method, and then parameters extracted from mentioned solution method consisted voltage magnitude and voltage angles of the busbar except the swing busbar. Following, active - reactive powers delivered in transmission lines and loss of transmission lines are calculated.

Optimal power flow analy sis satisfies such a load capacity scheme that minimizing system installation costs in power generating units, and by the same time the amplitudes and angles of all the bus voltages and reactive power calculations are successes. Design and operation of a power system is a very complex problem [3]. As a result of advances in computer technology, many simulation software packages have been created for power system analysis. The most general and reliable algorithm to solve the power flow problem is Newton-Raphson method $[4,5]$. 
In Newton-Raphson method, the basic principle of the load flow problem is solving the voltage of the busbar with generators and power system installation using the system loads given into non-linear equations. Load flow methods make calculation of the maximum loading point easy and also all the PV curve is drawn by Newton-Raphson method. PV curve is usually used as an aid for electrical power system planning and analy sis.

Increased load models under conditions of high voltage borders are difficult to predict. Mostly this can be estimated by using these curves. Almost all load flow methods are based on the prediction approach. In this case, the load demand during the power systems maximum loading point, the power system is meant to reach a balanced point of voltage limit. Under normal circumstances, load flow equations have possible two solutions and one of them gives operational point of electrical power system $[6,7]$.

In this study, 16 buses section from 118 buses interconnected 420 and $170 \mathrm{kV}$ Marmara region electrical power transmission lines are discussed. Additionally, power flow and critical fault condition analysis of newly installed transmission lines, additional transformers and generating power units possibly installed in coming future was performed.

Power flow and critical fault condition analy sis of mentioned electrical power system are solved by using the PSAT 2.1.9 software [8]. This study consists of four chapters and appendices. In the first section, the subject of paper introduced in general and some studies relative with the subject are presented. In the second section, Marmara region electrical power system briefly introduced. In the third section implementing PSAT 2.1.9 software programs in Marmara region electrical power sy stem is described and data network, optimal load flow analy sis was conducted with three steps critical fault condition analy sis.

These steps include outage of shunt capacitor unit analy sis, outage of series capacitor unit analy sis, and inline of critical short circuit analy sis. The fourth section is conclusion part of this study. This section summarizes effects of Marmara region electrical power sy stem stability under the critical fault condition analy sis on power transmission lines.

\section{Description of the Marmara Region Electrical Power System}

Marmara region electrical power system is required to ensure continuous operation of productionconsumption balance. This is a central control and direction system to ensure mentioned power balance. In very large power systems, system areas are divided into more than one region and these divided substations are controlled under their local centers. One of the power sy stem regions in Turkey electrical transmission network is the Marmara region electrical power transmission network. Production and consumption balance must be kept continuously in interconnected system operating. It is possible to keep this balance thereby controlling from one center. For very big systems, these zones are controlled from their own centers thereby dividing the system as zones more than one. Marmara region electrical power transmission zone is one of zones in Turkey. Reduced 16 buses section from Marmara region electrical power system map is given in figure 1. 


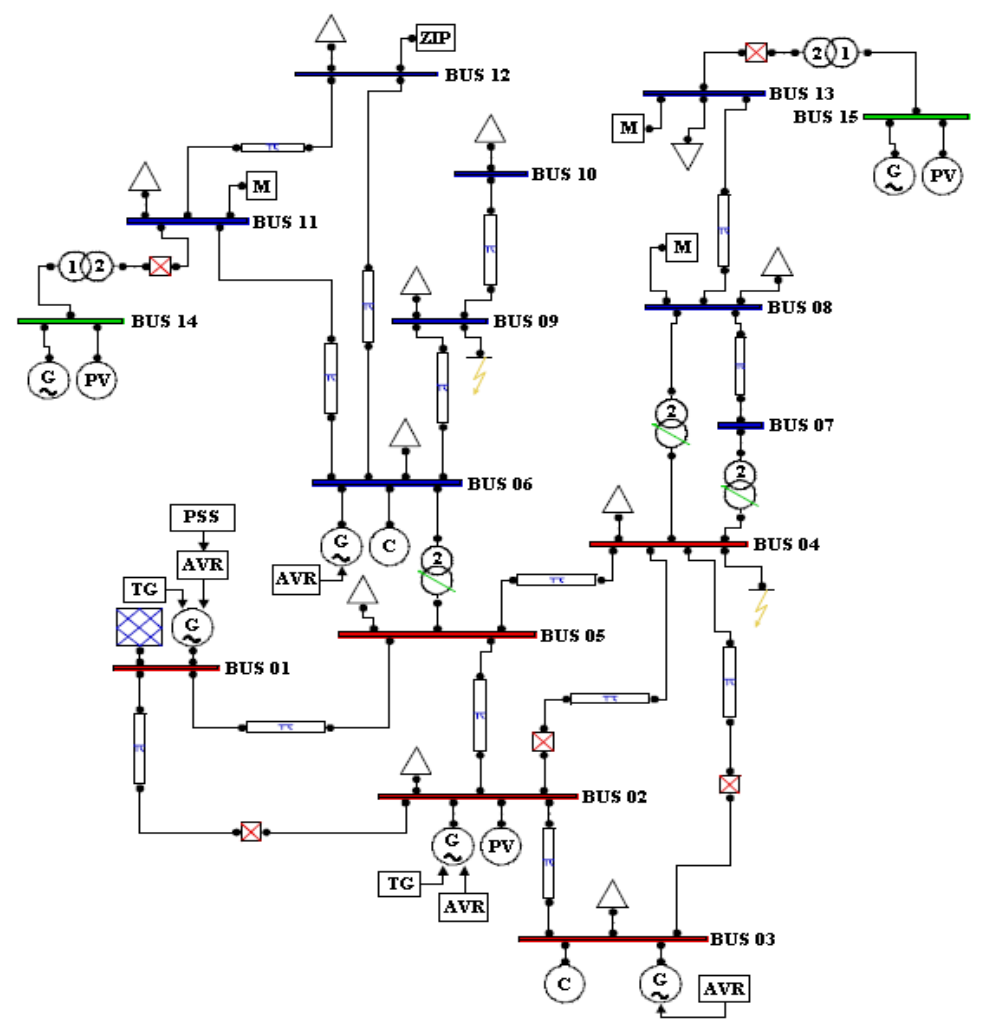

Fig. 1. Reduced 16 buses section from Marmara region electrical power system map

Existing operation voltage in Marmara region electrical power system is $170 \mathrm{kV}$ and $420 \mathrm{kV}$. There are 13 buses with $420 \mathrm{kV}$ and 105 buses with $170 \mathrm{kV}$ in this region. Among these 118 buses, 20 buses are for production and 98 buses are for load bus. In this sy stem there are 7 auto producer power plants, 4 special power plants, 7 thermal power plants and 2 hydraulic power plants. All 420 and $170 \mathrm{kV}$ transmission line rates in the system were conversed the PU (per unit) system to adapt [9].

In PSAT 2.1.9 program, characteristic rate of autotransformers were used. Numbers were given from 1 to 118 for all buses. Auto producer and free production power plants which are connected to the electrical power system from medium voltage level did not exist but existing power plants which have special $170 \mathrm{kV}$ switchyard (Enerjisa, Entek) were considered however produced at medium voltage level. $380 \mathrm{kV}$ Ada DGKCS-1 transformer center was selected as slack bus thereby writing bus voltage rate for each bus. Power flow analy sis was made thereby accepting the transmission loss provided from this bus. Indeed, this bus already is a high generator bus. Table 1 codes are defined for the buses from 1 to 16 in the Marmara region electrical power transmission network and each bar code is used in later studies. Impedances of reduced 16 buses section from Marmara region electrical power system are given in table 2. Angles and load status information in the reduced 16 buses electrical power system are given in table 3 .

Table 4. Buses names and codes for given 16 buses

\begin{tabular}{cccc}
\hline Bus Number & Bus Name & Bus Number & Bus Name \\
\hline 1 & 420 Ada DGKCS-1 & 9 & 420 Adapazarı \\
2 & Köseköy & 10 & Karasu \\
3 & Arslanbey & 11 & Sakarya \\
4 & Izmit Gis & 12 & Kaynarca \\
5 & Hyundai & 13 & Hendek \\
6 & Toyota & 14 & Kuzuluk
\end{tabular}


International Conference on Energy Efficiency Engineering, Nov 2015

\begin{tabular}{llll}
7 & Yarımca-1 & 15 & Goksu Hes \\
8 & Yarımca-2 & 16 & Adapazar1 \\
\hline
\end{tabular}

Table 2. Impedances of reduced 16 buses section from Marmara region electrical power system

\begin{tabular}{ccccc}
\hline From Bus & To Bus & $\mathrm{R}(\mathrm{pu})$ & $\mathrm{X}(\mathrm{pu})$ & $\mathrm{Y}(\mathrm{pu})$ \\
\hline 420 Ada DGKCS-1 & 420 Adapazarı & 0.000469 & 0.004334 & 0.096258 \\
Adapazar1 & Köseköy & 0.011959 & 0.056119 & 0.024037 \\
Köseköy & Arslanbey & 0.001546 & 0.006486 & 0.084544 \\
Köseköy & Izmit Gis & 0.012467 & 0.037456 & 0.014778 \\
Adapazar1 & Hyundai & 0.024641 & 0.079038 & 0.027088 \\
Hyundai & Toyota & 0.002675 & 0.014587 & 0.005368 \\
Adapazarı & Yarımca-1 & 0.017758 & 0.083332 & 0.035693 \\
Adapazar1 & Yarımca-2 & 0.017512 & 0.081327 & 0.033411 \\
Adapazar1 & Sakarya & 0.011660 & 0.057846 & 0.012442 \\
Kuzuluk & Goksu Hes & 0.005476 & 0.040663 & 0.025366 \\
Adapazar1 & Karasu & 0.036744 & 0.074525 & 0.063533 \\
Adapazar1 & Hendek & 0.032256 & 0.103462 & 0.035458 \\
Adapazarı & Kaynarca & 0.019411 & 0.062263 & 0.021339 \\
Hyundai & Izmit Gis & 0.015363 & 0.065836 & 0.045664 \\
\hline
\end{tabular}

Table 3. Load angles and load status of reduced 16 buses section from Marmara region electrical power system at date 30.08 .2015

\begin{tabular}{ccccc}
\hline Buses & Active Power & Reactive Power & Apparent Power & Angle \\
\hline 420 Ada DGKCS-1 & 1632.000 & 435.000 & 1703.645 & 13.675 \\
420 Adapazarı & 1921.230 & 565.470 & 1995.435 & 14.096 \\
Köseköy & 100.360 & 64.600 & 127.890 & 34.676 \\
Karasu & 14.300 & 3.900 & 14.854 & 17.564 \\
Arslanbey & 74.500 & 21.500 & 78.445 & 12.431 \\
Sakarya & 52.360 & 11.425 & 56.261 & 13.539 \\
Izmit Gis & 95.320 & 62.580 & 110.243 & 31.365 \\
Kaynarca & 12.800 & 4.230 & 13.576 & 19.245 \\
Hyundai & 64.700 & 9.545 & 67.320 & 7.418 \\
Hendek & 39.670 & 9.230 & 42.023 & 26.452 \\
Toyota & 66.300 & 21.500 & 69.328 & 15.219 \\
Kuzuluk & 23.240 & 5.670 & 24.025 & 9.254 \\
Yarımca-1 & 44.600 & 15.750 & 48.238 & 20.583 \\
Göksu Hes & 12.100 & 4.400 & 12.927 & 13.496 \\
Yarımca-2 & 41.680 & 21.650 & 45.325 & 17.439 \\
Adapazarı & 336.680 & 193.620 & 371.395 & 29.329 \\
\hline
\end{tabular}

Only power production bus of the Marmara region electrical power system (as well as the slack bus) is $420 \mathrm{kV}$ Ada DGKCS-1. The production of active power is $1672 \mathrm{MW}$ and reactive power is 193 MVAr in this slack bus.

Roles of Marmara region electrical power system;

1. Provision of electricity production and transmission, according to consumer needs. 2. System voltage and frequency to be kept within certain limits, and load shedding. 3. Conduct of the business, the coordination of maneuvers and get the work done.

\section{Critical Fault Condition Analyses}

The critical fault condition analyses are investigated into three different scales.

- Short circuit analysis,

- Outage series capacitor unit analy sis,

- Outage shunts capacitor unit analy sis. 
The critical fault condition analyses are handled into three different cases.

Case 1: The electrical power system with normal load in all the load buses is considered as normal condition and the Newton-Raphson load flow is carried out with loading factor value equal to 1 .

Case 2: The electrical power system with $50 \%$ increased load in all the load buses is considered as a critical condition. Loading of the electrical power system went beyond this level and results in poor voltage profile in the load buses and unacceptable real power loss level.

Case 3: Contingency is imposed by considering the most critical line outage in the electrical power system. This is the most suitable condition for voltage stability analy sis of a power system as voltage stability is usually triggered by line outages.

The critical fault condition cases one line diagram is given in figure 2 .

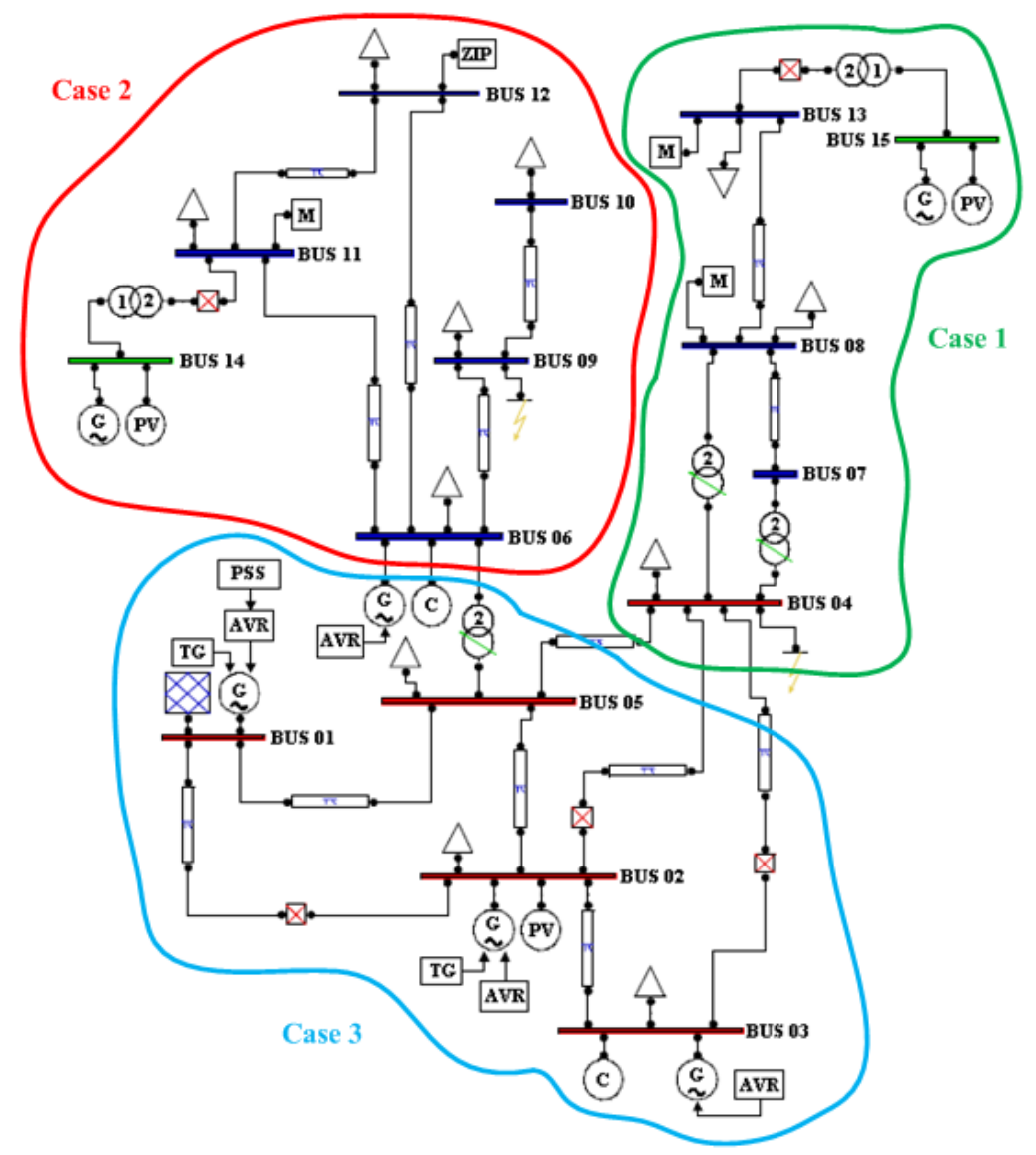

Fig. 2. The critical fault condition cases one line diagram

\subsection{Short Circuit Analysis}

Electric current carrying circuits, especially in power systems containing high voltage, short circuit is common situation. In such a situation are of very great dangers. Short circuit calculations, the worst possibility that the three phase short circuit state is considered. The short circuit analysis one line diagram for case 1 is given in figure 3. The short circuit calculation PSAT 2.1.9 program screenshot is shown in figure 4. As an example, three phase short circuit was created in Izmit Gis bus and the results are given in table 4. 


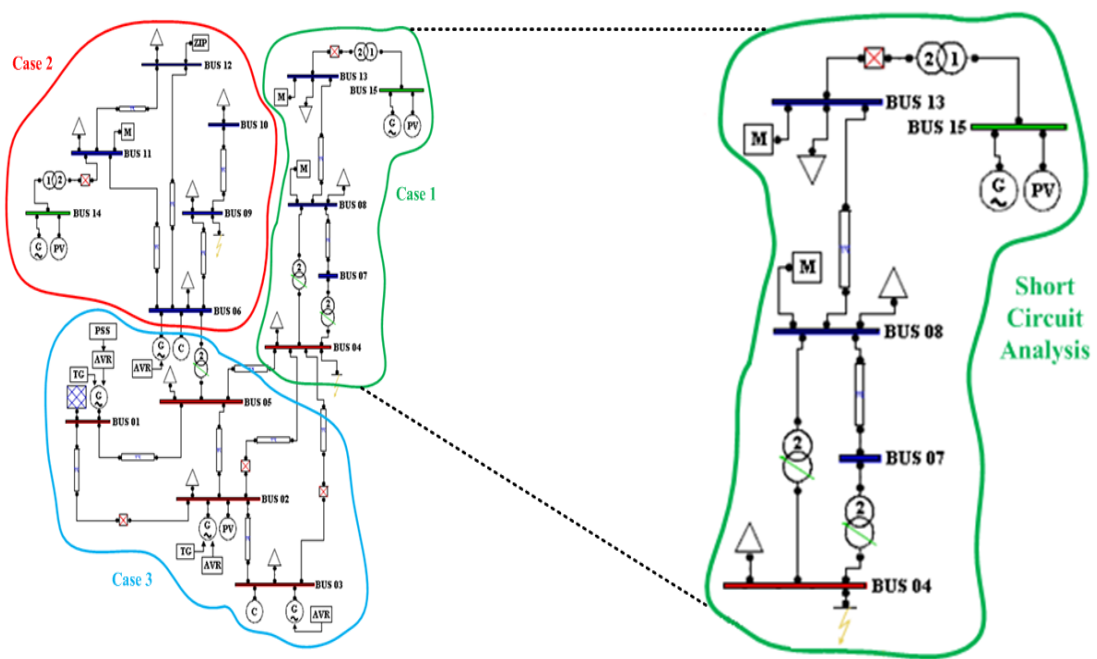

Fig. 3. The short circuit analy sis one line diagram for case 1

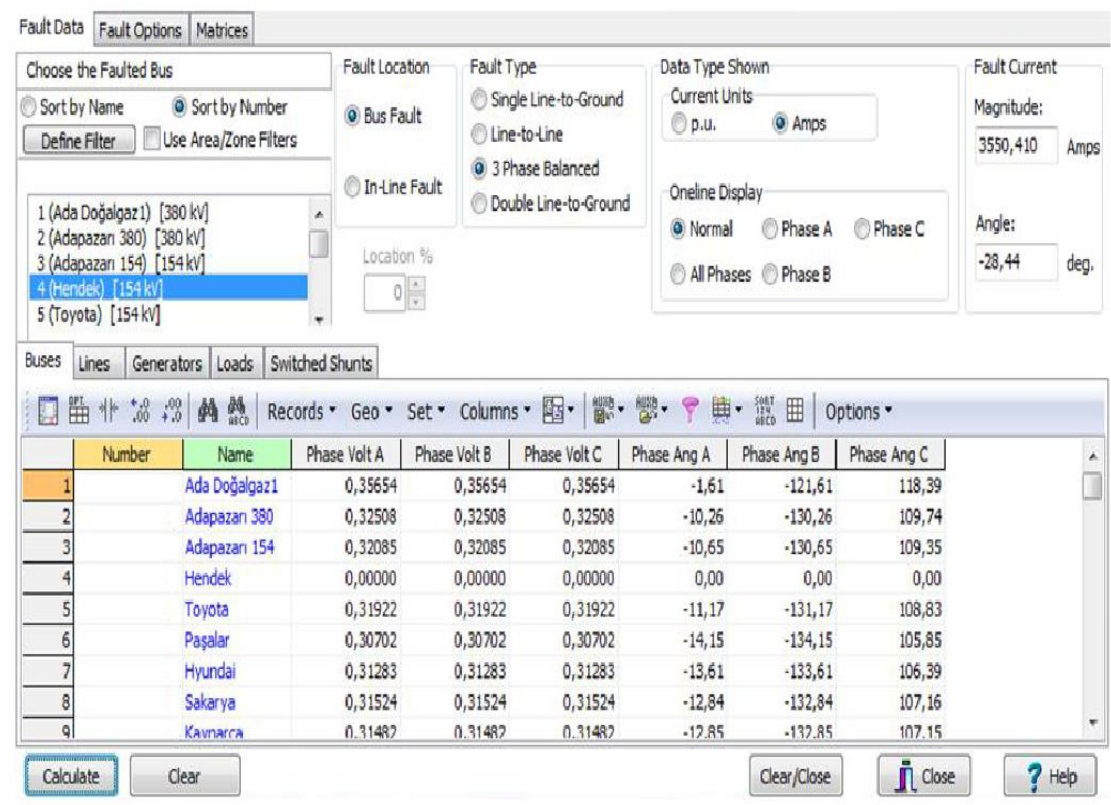

Fig. 4. The short circuit calculation PSAT 2.1.9 program screenshot

Table 4. Result of short circuit analy sis in Izmit Gis bus for case 1 using PSAT 2.1.9 program

\begin{tabular}{ccccccc}
\hline \multirow{2}{*}{$\begin{array}{c}\text { Bus } \\
\text { Number }\end{array}$} & \multicolumn{3}{c}{ Voltage } & \multicolumn{3}{c}{ Angle } \\
\cline { 2 - 7 } & A Phase & B Phase & C Phase & A Phase & B Phase & C Phase \\
\hline 1 & 0.3462 & 0.3462 & 0.3462 & -1.52 & -121.43 & 119.28 \\
2 & 0.3138 & 0.3138 & 0.3138 & -11.38 & -130.48 & 112.16 \\
3 & 0.3265 & 0.3265 & 0.3265 & -10.73 & -129.35 & 110.76 \\
4 & 0.0000 & 0.0000 & 0.0000 & 0.0000 & 0.0000 & 0.0000 \\
5 & 0.3172 & 0.3172 & 0.3172 & -13.46 & -132.88 & 107.53 \\
6 & 0.3092 & 0.3092 & 0.3092 & -11.37 & -131.47 & 109.37 \\
7 & 0.3185 & 0.3185 & 0.3185 & -10.54 & -127.51 & 113.18 \\
8 & 0.3129 & 0.3129 & 0.3129 & -11.82 & -130.89 & 111.45
\end{tabular}


International Conference on Energy Efficiency Engineering, Nov 2015

\begin{tabular}{ccccccc}
\hline 9 & 0.3383 & 0.3383 & 0.3383 & -10.55 & -130.82 & 110.56 \\
10 & 0.3165 & 0.3165 & 0.3165 & -12.88 & -128.25 & 109.65 \\
11 & 0.3151 & 0.3151 & 0.3151 & -11.47 & -131.24 & 108.14 \\
12 & 0.3148 & 0.3148 & 0.3148 & -12.39 & -130.37 & 107.98 \\
13 & 0.3175 & 0.3175 & 0.3175 & -10.46 & -130.86 & 109.85 \\
14 & 0.3205 & 0.3205 & 0.3205 & -11.53 & -128.73 & 110.81 \\
15 & 0.3152 & 0.3152 & 0.3152 & -10.38 & -128.55 & 109.35 \\
16 & 0.3169 & 0.3169 & 0.3169 & -11.08 & -130.67 & 111.64 \\
\hline
\end{tabular}

\subsection{Outage Series Capacitor Unit Analysis}

Series capacitors are connected in series with the electrical power transmission line by the aim for compensating for inductive reactance (and also reducing the impedance of the transmission line). Series Capacitors also increases the maximum power and reduces loss of transmitted reactive power in transmission line [10]. The outage series capacitor unit analy sis one line diagram for case 3 is given in figure 5.

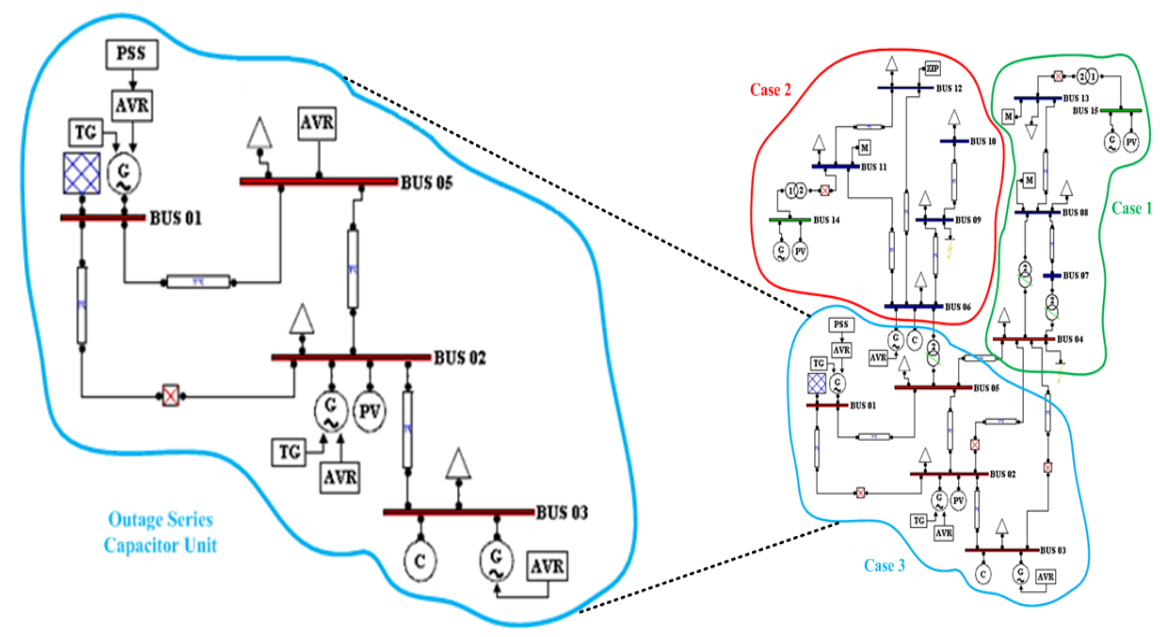

Fig. 5. The outage series capacitor unit analy sis one line diagram for case 3

In the case of outage series capacitor unit, establishing different proportions of series compensation on electrical power system decreases the continuous load carrying capacity in power transmission lines. Marmara region electrical power transmission line PV curve status in the case of outage series capacitor unit is given in figure 6. As shown in figure 6, PV curves voltage collapse cases has been shifted from $1.45 \mathrm{pu}$ (per-unit) voltage level to never collapse cases. 


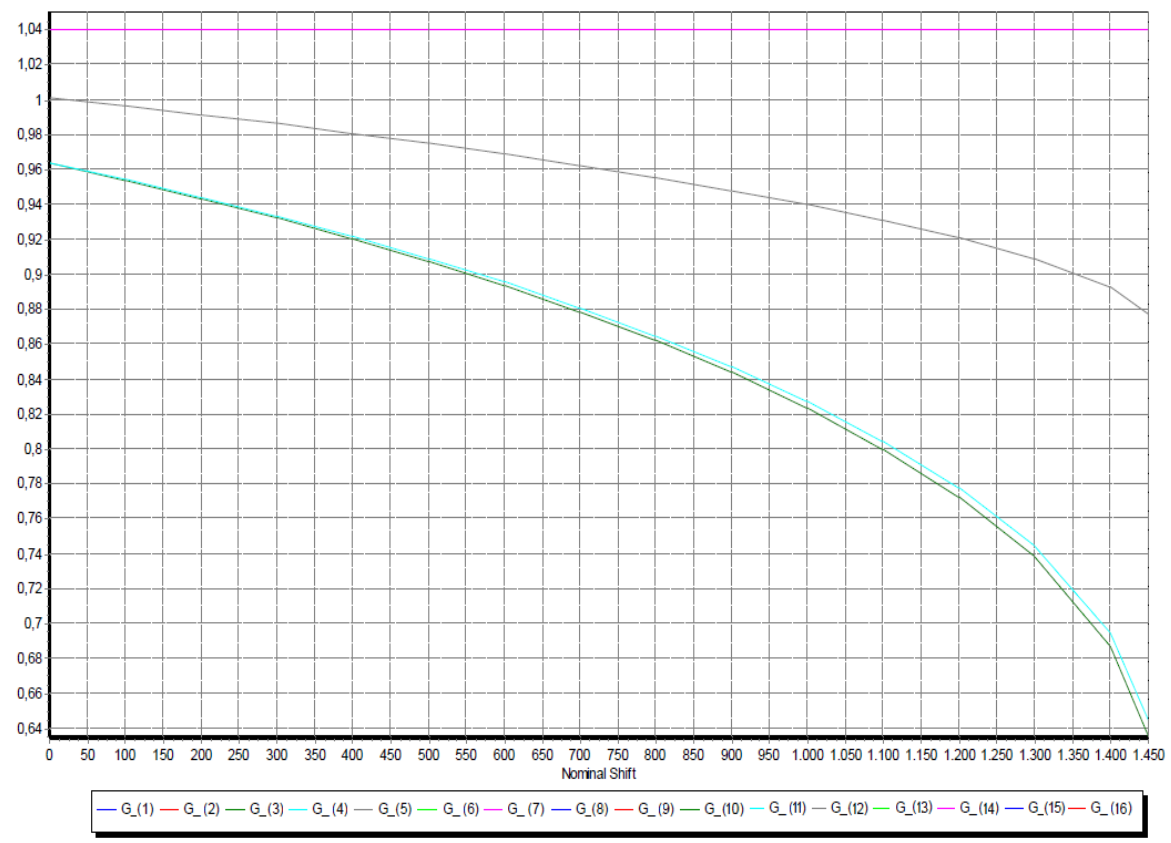

Fig. 6. Transmission line PV curve status in the case of outage series capacitor unit

\subsection{Outage Shunts Capacitor Unit Analysis}

Shunt capacitors group connected to power transmission line in parallel, increase bus voltage and generate reactive power. In general, they are used to produce reactive energy that consumers needed. Parallel capacitors provide reactive power and help to sustain voltages into acceptable limits [11]. The outage shunts capacitor unit analy sis one line diagram for case 2 is given in figure 7 .

In the case of outage shunts capacitor unit, establishing different proportions of shunts compensation on electrical power system decreases the continuous load carrying capacity in power transmission lines. Marmara region electrical power transmission line PV curve status in the case of outage shunts capacitor unit is given in figure 8. As shown in figure 8, PV curves voltage collapse cases has been shifted from $1.30 \mathrm{pu}$ (per-unit) voltage level to never collapse cases. The amount of reactive power from slack bus decreases before the outage shunts capacitor unit. 


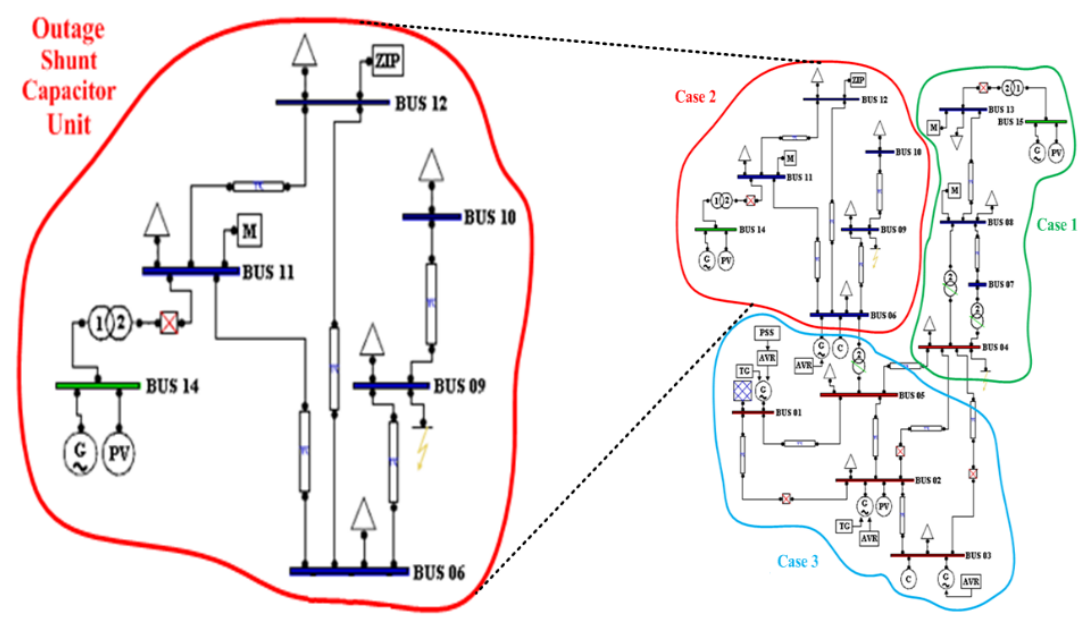

Fig. 7. The outage shunts capacitor unit analy sis one line diagram for case 2

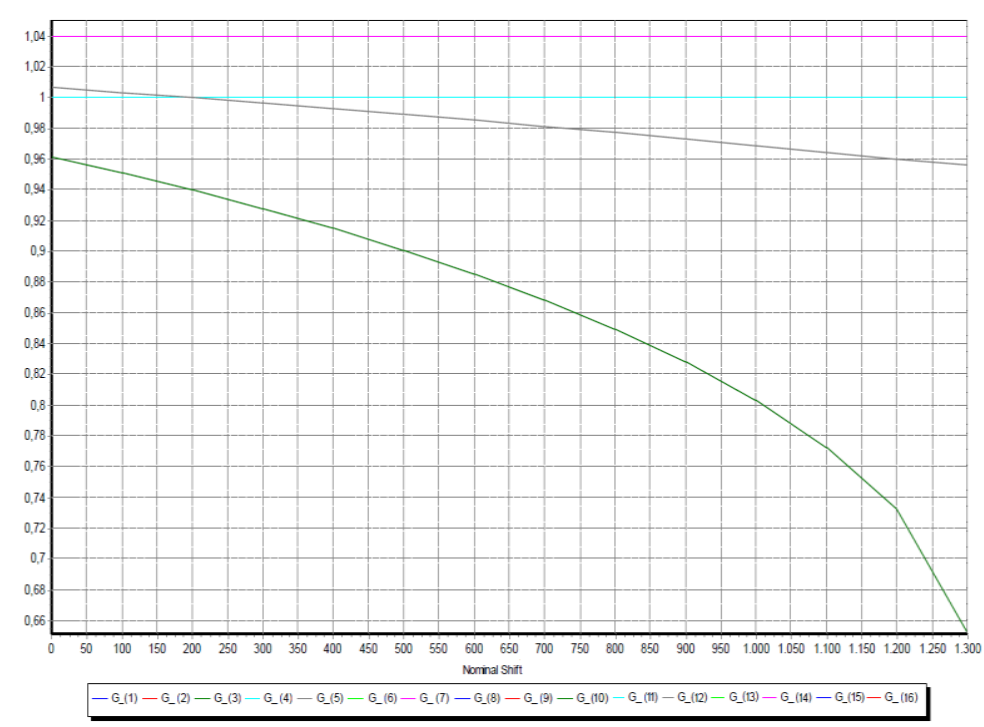

Fig. 8. Transmission line PV curve status in the case of outage shunts capacitor unit

\section{Conclusions}

Power flow, power system stability and critical fault condition analysis is an important criterion for operation of electrical power systems. Modern electrical power systems are planned for high level, multi-variable dynamic sy stems. Electrical power system planning, design and operation requires special attentions on careful evaluation and analy sis schemes for providing high system performance, reliability, and healthy economic operability. Modern interconnected electrical power networks are composed of thousands of system elements and buses. Manual calculation may take great times. Today, Power analysis programs which run very short period of time are widely used for giving healthy outputs. Therefore, in this study, critical fault condition analysis of 16 buses sample of Marmara region electrical power system stability is investigated by using PSAT 2.1.9 program. 


\section{References}

1. Reis, C., Barbosa F.P.M.: A Comparison of Voltage Stability Indices, IEEE Mediterraneen Electrotechnical Conference (MELECON), (2006) 1007-1010

2. Hotunluoglu, H., Karakaya, E.: Forecasting Turkey's Energy Demand Using Artificial Neural Networks: Three Scenario Applications, Ege Academic Review, vol. 11, special issue (2011) 87 94

3. Pamuk, N.: Multivariable Adaptive Hybrid Control Model for Interconnected Power Systems at the Inception of Voltage Collapse, Afy on Kocatepe University Journal of Science and Engineering, vol. 15 , no. 2, (2015) 7-17

4. Abbasbandy, S.: Improving Newton - Raphson Method for Nonlinear Equations by Modified Adomian Decomposition Method, Applied Mathematics and Computation, vol. 145, no. 2-3, (2003) 887-893

5. Pamuk, N., Uyaroglu, Y.: Comparison the 154 and $380 \mathrm{kV}$ Transmission System Network of Northwest Anatolia by Making Power Flow Emulation with Constraint Analysis in Turkey, Scientific Research and Essays, vol. 6, no. 2, (2011) 469-478

6. Abido, M.A.: Optimal Power Flow Using Particle Swarm Optimization, International Journal of Electrical Power \& Energy Systems, vol. 24, no. 7, (2002) 563-571

7. Das, D., Kothari, D.P., Kalam, A.: Simple and Efficient Method for Load Flow Solution of Radial Distribution Networks, International Journal of Electrical Power \& Energy Systems, vol. 17, no. 5, (1995) 335-346

8. Milano, F.: Power System Analysis Toolbox: Documentation for PSAT version 2.1.9 (2014) Available: http://faraday 1.ucd.ie/psat.html

9. Pamuk, N.: Power Flow Simulation for 380 and 154 Kv Northwest Anatolia Network in Turkey, Master's Dissertation, University of Sakarya, Sakarya, Turkey (2009) (in Turkish)

10. Magaji, N., Mustafa, M.W.: Optimal Thy ristor Control Series Capacitor Neuro - Controller for Damping Oscillations, Journal of Computer Science, vol. 5, no. 12, (2009) 980-987

11. Aman, M.M., Jasmon, G.B., Bakar, A.H.A., Mokhlis, H., Karimi, M.: Optimum Shunt Capacitor Placement in Distribution Sy stem - A Review and Comparative Study, Renewable and Sustainable Energy Reviews, vol. 30, (2014) 429-439 